\title{
EFFECTIVENESS OF SELECTED PRESERVATIVES IN PROTECTING UGANDAN GROWN EUCALYPTUS GRANDIS WOOD AGAINST TERMITE ATTACK
}

\author{
I. E. Ssemaganda ${ }^{1}$, P. Mugabi ${ }^{1}$, S. B.Tumwebaze ${ }^{2}$
}

\begin{abstract}
Termites are one of the major wood destroying agents in the tropics and with the increasing rate of deforestation, there is a need to protect wood from biodegradation in order to extend its service life. In this study the incidence and severity of termite attack on Eucalyptus grandis sapwood treated with CCA, used engine oil and neem extract were investigated. Sixty samples $(20 \times 20 \times 300 \mathrm{~mm})$ were prepared from the sapwood at mid-height of the tree of E. grandis and air seasoned for two weeks then treated with the preservatives. An area of $20 \mathrm{~m}$ by $20 \mathrm{~m}$ in a pine plantation and 15 plots of $1 \mathrm{~m}$ by $1 \mathrm{~m}$ were selected at random. Four samples, one from each treatment, were placed at the corners of the selected plots.

Inspection and evaluation of stakes was made by visual assessments after every 30 days for any sign of termite attack for a period of 8 months. The specimens were removed from the ground, damage assessed and returned to the ground. After 4 weeks all the untreated wood samples had been attacked, neem extract treated wood samples were attacked after 17 weeks and used engine oil treated samples after 30 weeks. None of the CCA treated wood samples were attacked by the end of study period. Chi square analysis showed a high association between treatment and incidence as well as between treatment and severity. It was recommended that further research be carried out on neem extract using different concentrations.
\end{abstract}

Keywords: Eucalyptus grandis, preservatives, termite attack, Uganda

\section{INTRODUCTION}

Bowyer et al. (2003) indicated that wood products in use throughout the world are subject to infestation by insects. The same authors further noted that of the insects, termites have by far the greatest economic importance. Termites destroy wood by feeding on its components, thereby reducing its structural ability and appearance. Cellulose being the principal food of termites, wood and wood products such as paper, fabrics and wood structures are avidly consumed, and hence, a constant effort is directed towards their control (Peralta et al. 2004).

Eucalyptus grandis is one of the widely used construction tree species in Uganda. It is used for electricity poles, fence posts and roof trusses. However, in a survey carried out in Tororo district in Uganda, Nyeko and Olubayo (2005) reported that eucalyptus species are highly susceptible to termites. Some of the strategies to protect wood from termite attack include using naturally resistant tree species and applying toxic chemicals to wood. The common preservatives used in Uganda to protect wood against biodegrading agents are creosote, used engine oil and Chromated

\footnotetext{
${ }^{1}$ Department of Forest Products Engineering, Faculty of Forestry and Nature Conservation, Makerere University. Kampala, Uganda ${ }^{2}$ Department of Forest management, Faculty of Forestry and Nature Conservation, Makerere University. Kampala, Uganda. Received: 25.10 2010 Accepted: 17.03 2011.

Corresponding author: mugabi@forest.mak.ac.ug
} 
Copper Arsenate (CCA). Over the past few decades, there has been a substantial global quest to develop eco-friendly wood preservatives which do not cause any ill effect on the health of mammals (Venmalar and Nagaveni 2005). The search for effective bio-control methods for wood preservation is continuing but one that could be useful is the natural insect growth regulator, azadirachtin (AZA). This botanical compound can be effective yet it is biodegradable and rapidly metabolizes in the environment (Weathersbee and Tang 2002). AZA can be extracted from the seeds of Azadirachta indica i.e. the neem tree. According to Venmalar and Nagaveni (2005) neem possesses a number of toxic constituents exhibiting high toxicity against wood destroying microbes. However, the effectiveness of chemicals to control biological attack on wood depends upon the wood, the chemical used and the pests that are present and environmental conditions following treatment (Johnson, 2000). As Walker (1993) noted, the use of a single, universal wood preservative treatment does not provide optimal economy since the spectrum of hazards to which timber is exposed is wide both in type and severity. This spectrum of hazards includes attack by fungi, insects and marine borers, any of which can result in degradation at varying rates depending on the immediate environment. The objectives of the study were to determine (i) the incidence and (ii) severity of termite attack on E. grandis sapwood samples treated with CCA, used engine oil and neem extract.

\section{MATERIALS AND METHODS}

\section{Timber}

One Eucalyptus grandis tree of DBH $25 \mathrm{~cm}$ was felled from a wood lot in Masaka district, central Uganda. The tree was crosscut into three portions of $4 \mathrm{~m}$ each representing the butt, middle and top parts. The middle portion was further cross cut into two billets of $2 \mathrm{~m}$ each which were used to produce eight $20 \times 50 \times 2000 \mathrm{~mm}$ boards from the sapwood. Each board was then ripped into two $20 \times$ $20 \times 2000 \mathrm{~mm}$ scantlings (Fig. 1). Sixty samples of $20 \times 20 \times 300 \mathrm{~mm}$ were then prepared from the scantlings (Fig. 1) and air seasoned for two weeks to approximately $20 \%$ moisture content and then treated with the preservatives.

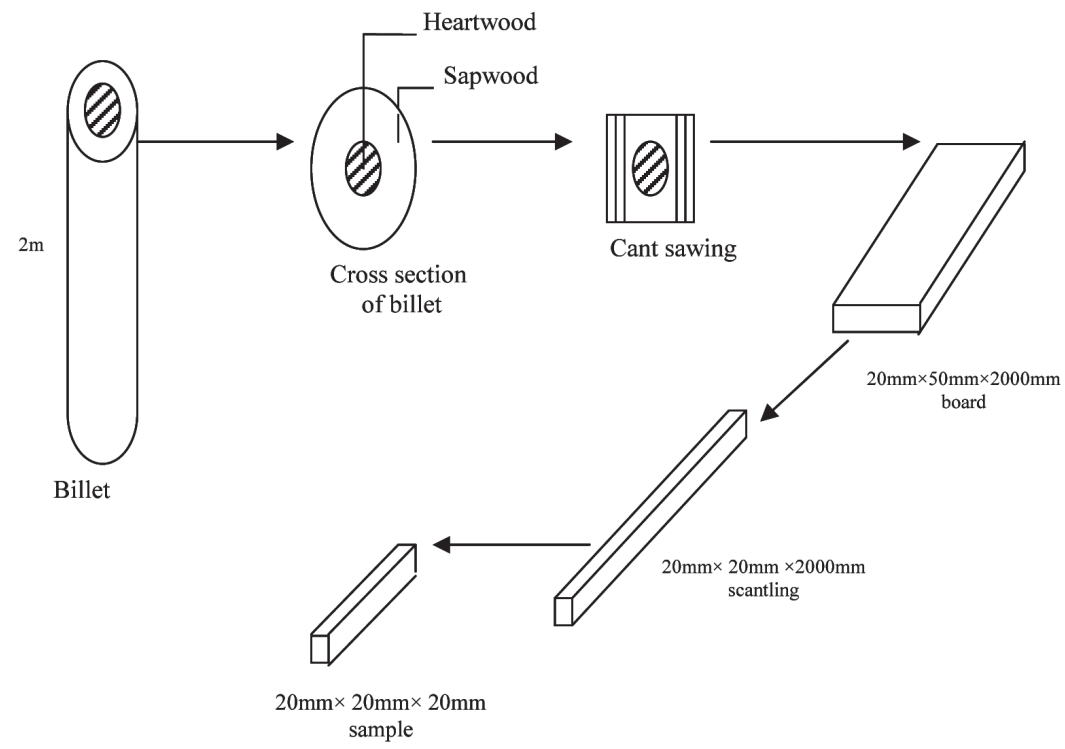

Figure 1. Preparation of wood samples from billet 


\section{Treatment of samples with preservatives}

Out of the 60 samples, 15 were treated with each preservative chemical i.e. CCA, used engine oil and neem extract, and 15 samples left untreated to act as control in the experiment. Steeping method was used to treat the samples since as Darrel (1973) observed retention levels using stakes should be held to low levels to allow early decay but still give longer levels of protection than controls.

For used engine oil treatment, three liters of used diesel engine oil were mixed with half a liter of diesel in a basin to make it less viscous in order to improve the penetration into wood. For neem extract treatment, two liters of Nimbecidine (azadirachtin $0.03 \%$ EC.) composed of neem bitter $(3.5 \%)$, neem oil $(75.5 \%)$, emulsifier $(10.0 \%)$, Product $110 \mathrm{R}(2.0 \%)$, and diluent $(9.0 \%)$ was used. The chemical formulation of CCA used to treat the specimens was copper oxide $-95 \mathrm{~g} / \mathrm{kg}$ of CCA ( $25.61 \%$ of CCA), chromium trioxide $-153 \mathrm{~g} / \mathrm{kg}$ of CCA $(41.24 \%$ of CCA), arsenic pentoxide $123 \mathrm{~g} / \mathrm{kg}$ of CCA (33.15\% of CCA). This was diluted to $4 \%$. The 15 samples were soaked in troughs containing the respective preservatives for 24 hours. After treatment, the 45 treated samples were left to drain for two weeks and together with the 15 control samples were then carried to the field in Nakasongola, central Uganda where they were subjected to termites. Each sample was marked at mid-length and buried in the soil up to this point i.e. $150 \mathrm{~mm}$.

\section{Study area description}

The experiment was done in Katuugo parish, Kakooge Sub County in Nakasongola district found in central Uganda. The district receives rainfall ranging from $500-1000 \mathrm{~mm}$ per annum in two main rain seasons: March-April-June/July and October to November/December (NDLG, 2004). Temperatures are high reaching a maximum of between $30^{\circ} \mathrm{C}-32^{\circ} \mathrm{C}$. Woodlands cover about 1276.9 $\mathrm{km}^{2}$ of the total land area of the district with approximately 1600ha of pine trees (P. oorcarpa and $P$. caribaea). About 1200 ha is woodland savanna and had never been planted. Woodlands are degrading to bushes and thickets and in some areas there are bare patches with no vegetation at all. In some areas woodland clearance has given a chance for Acacia spp and Lantana camara to dominate. This has been attributed mainly to excessive woodland harvesting for charcoal, annual bush fires which kill natural regenerating plants and termite activity which limits re-growth of any form of vegetation (NDLG, 2004).

According to NDLG (2004) termite activity in the district is one of the major militating factors against increase in agricultural output and efforts towards afforestation.

\section{Arrangement of samples in the field}

An area of $20 \mathrm{~m}$ by $20 \mathrm{~m}$ was selected in a pine plantation and 15 plots of $1 \mathrm{~m}$ by $1 \mathrm{~m}$ were selected at random. Four samples, one from each treatment, were placed at the corners of the selected plots (Fig. 2).

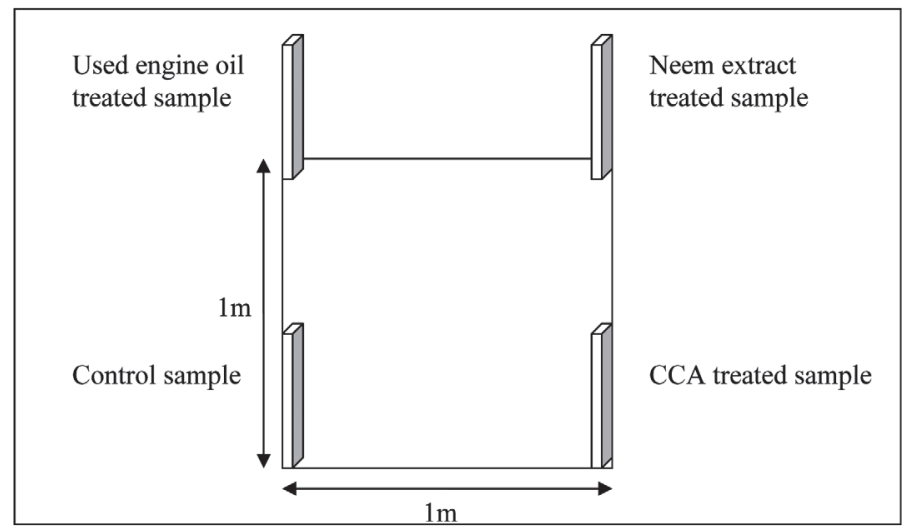

Figure 2. Arrangement of samples in the field 


\section{Data collection procedure}

Inspection and evaluation of stakes was made by visual assessments after every 30 days for any sign of termite attack for a period of 8 months. The specimens were removed from the ground and cleaned, and then the damage assessed. The incidence of termite attack was recorded as follows: 1 representing attacked; and 0 represented not attacked. The severity of the damage was recorded as follows: 1 representing less than $1 \%$ of total wood volume eaten; 2 for $1-20 \%$ of total wood volume eaten; 3 for $21-40 \%$; 4 for $41-60 \%$; and 5 representing above $60 \%$ of total wood volume eaten.

\section{Data analysis}

Percentages of specimens attacked by termites and counts of samples in each severity class for the different months were summarized. Descriptive statistics were used to determine the modal incidence of attack and modal severity of termite damage on samples treated with different chemicals as well as the variations of severity of attack in the different treatments over the eight months of the experiment. Chi square analysis was used to determine the association between treatment and incidence as well as treatment and severity. Chi square test was carried out at 5\% level of significance.

\section{RESULTS}

\section{Incidence of termite attack}

After only one month of the experiment, all the 15 (100\%) untreated samples were attacked (Fig. 3). For the first four months, none of neem extract, used engine oil and CCA treated samples was attacked as seen in figure 3. By the end of the 8 months $14(93 \%)$ of the neem extract treated samples were attacked and only $4(27 \%)$ of the samples treated with used engine oil were attacked (Fig. 3). None of the CCA treated samples were attacked by termites for the whole study period (Fig. 3).

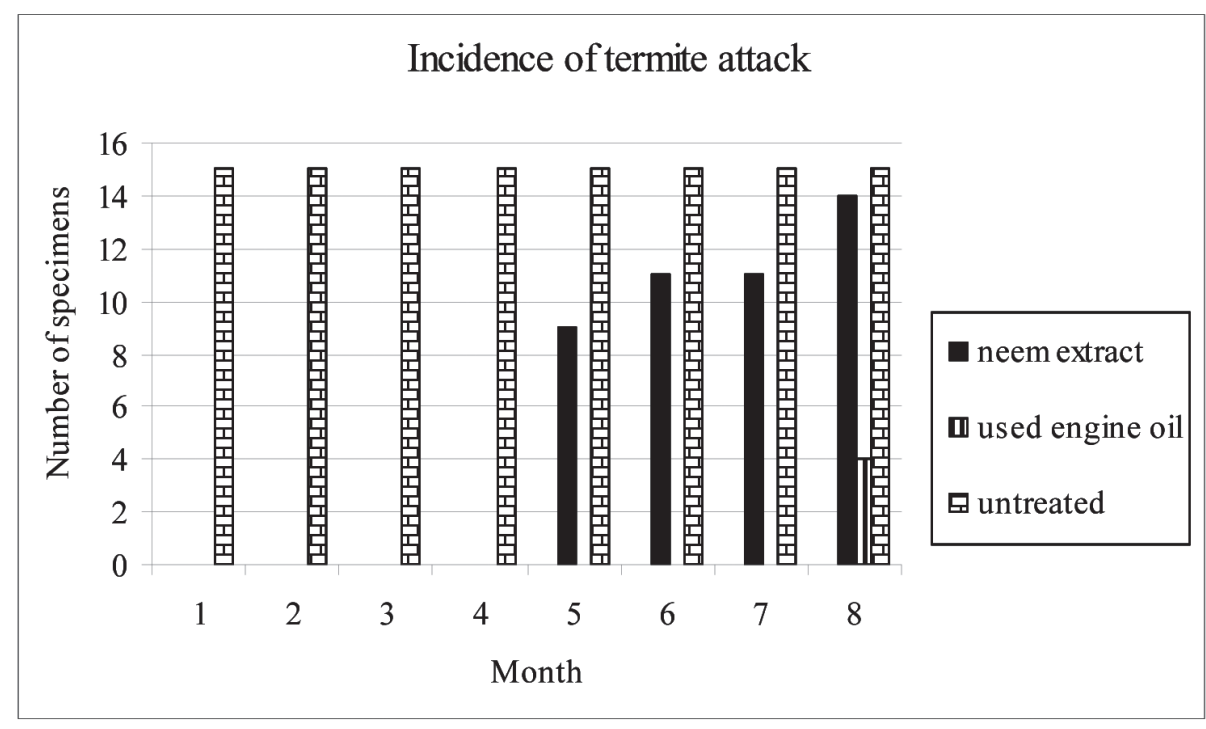

Figure 3. Number of specimens attacked for each treatment in each month since establishment of the experiment 


\section{Severity of termite attack}

Figure 4 shows that after 1 month all the CCA, neem extract and used engine oil treated samples were still in severity class 1 (less than $1 \%$ of total wood volume eaten) where as more than half of the untreated samples were already in severity class 3 (21-40\% of wood sample volume eaten up). After 8 months 13 of the 15 untreated samples were in severity class 5 (over $60 \%$ sample volume eaten) with 6 of the 15 samples completely eaten up by termites. More than half of the neem extract treated samples were in severity class 2 (1-20\% of sample volume eaten) and 1 sample was in severity class 5 after 8 months (Fig. 4). Most of used engine oil treated samples were not attacked at all after 8 months (Fig. 3) with only 4 attacked samples in severity class 2 (Fig.4).

Month 1

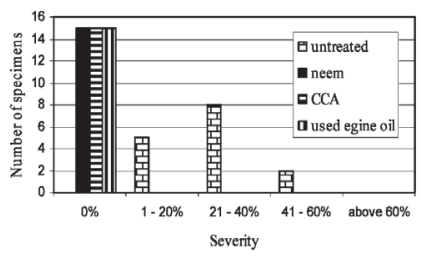

Month 3

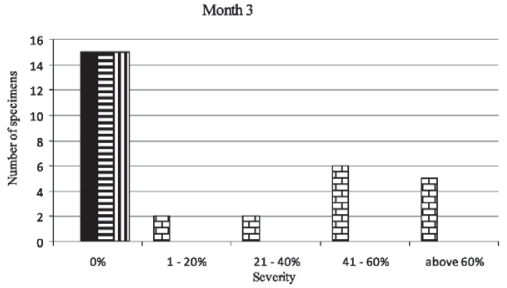

Month 5

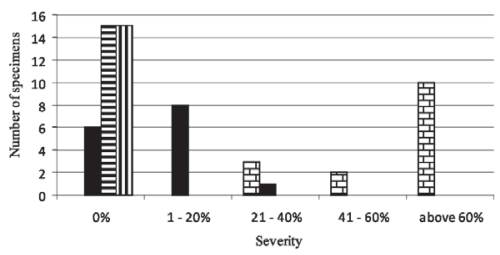

Month 7

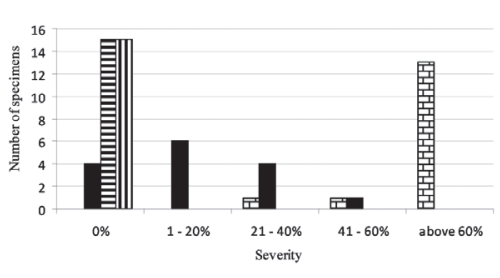

Month 2
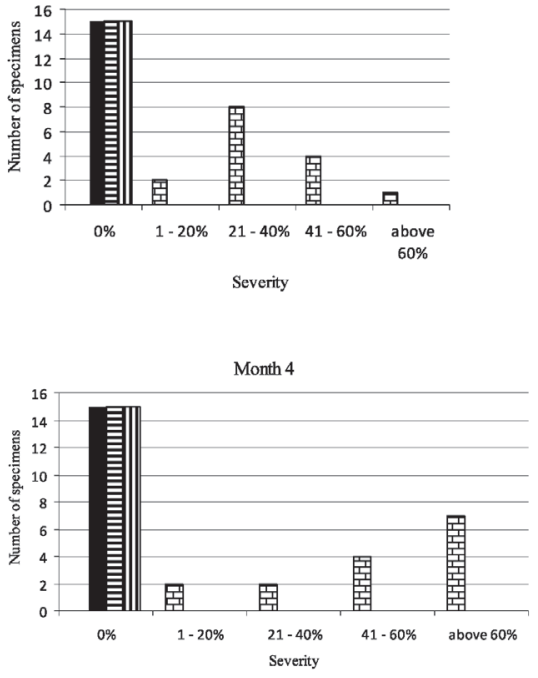

Month 6

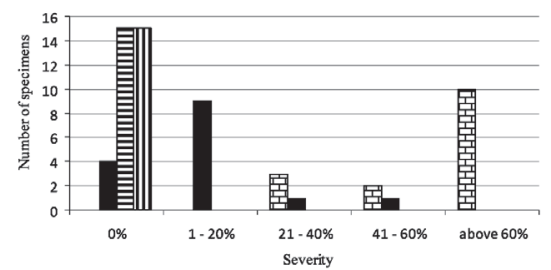

Month 8

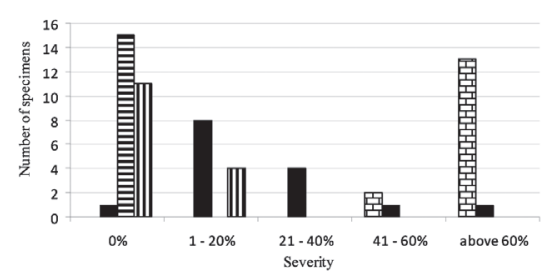

Figure 4. Number of specimens treated with different preservatives in different severity classes of termite infestation at different months after establishment of the experiment 
The modal severity of untreated samples after 1 month was 3 (21-40\% of sample volume eaten) where as it was class 1 (less than $1 \%$ of sample volume eaten) for CCA, neem extract and used engine oil (Table 1). After 8 months most of the untreated samples were in severity class 5 (above $60 \%$ of sample volume eaten) and severity class 2 (1-20\% of sample volume eaten) for neem extract., most of used engine oil and CCA treated samples were in severity class 1 after the 8 months (Table 1 ).

Table 1. Modal severity of specimens treated with different preservatives at different months after establishment of experiment.

\begin{tabular}{|l|c|c|c|c|c|c|c|c|}
\hline \multicolumn{7}{|c|}{ Month } \\
\hline Treatment & 1 & 2 & 3 & 4 & 5 & 6 & 7 & 8 \\
\hline Untreated & 3 & 3 & 4 & 5 & 5 & 5 & 5 & 5 \\
\hline Neem extract & 1 & 1 & 1 & 1 & 2 & 2 & 2 & 2 \\
\hline CCA & 1 & 1 & 1 & 1 & 1 & 1 & 1 & 1 \\
\hline Used engine oil & 1 & 1 & 1 & 1 & 1 & 1 & 1 & 1 \\
\hline
\end{tabular}

Key: 1, 2, 3, 4, and 5 are severity classes representing $0 \%, 1-20 \%, 21-40 \%, 41-60 \%$ and above $60 \%$ of wood sample volume eaten by termites respectively.

\section{Association between treatment and incidence}

Chi square $\left(\mathrm{x}^{2}\right)$ analysis showed that there was a significant association between treatment and incidence $\left(\mathrm{p}<0.05, \mathrm{X}^{2}=450.626, \mathrm{DF}=12\right)$. This indicates that the incidence of attack will depend on the type of treatment applied on the stakes. From the cross tabulation of incidence and treatment, the untreated specimens were more likely to be attacked by termites ( $71 \%$ within incidence) compared to neem extract $(26.6 \%$ within incidence), used engine oil $(2.4 \%)$ and CCA $(0 \%)$. CCA was the least likely to be attacked by termites.

\section{Association between treatment and severity}

Chi square $\left(\mathrm{x}^{2}\right)$ test indicated a significant association between treatment and severity $(\mathrm{p}<0.05$, $\mathrm{X}^{2}=339.760, \mathrm{DF}=3$ ). This indicates that the severity of attack depends on the type of treatment applied on the stakes. From treatment-severity cross tabulation, the untreated were the most likely to be severely attacked with $98.3 \%$ of the samples in severity class 5 (above $60 \%$ wood volume eaten) followed by neem extract samples $(0.8 \%$ within severity class 5$)$.

\section{DISCUSSION}

All the untreated samples were attacked in the first month of establishment of the experiment because sapwood of $E$. grandis is highly susceptible to termite attack and offers no resistance. Any resistance offered would be due to the chemical treatment. For the first 4 months all treated samples irrespective of the chemical used were not attacked because the chemicals offered resistance to the termites.

There was a high association between the treatment and incidence of termite attack and between treatment and severity of termite attack. This is in agreement with what Johnson (2000) observed that the effectiveness of chemicals to control biological attack on wood depends upon the chemical used since different chemicals contain different toxicity levels. CCA protected the samples against termites throughout the 8 months of the experiment because the arsenic component in CCA is highly toxic to termites. The chromium component helps the other components to fix in the timber, binding 
them through chemical complexes to the wood's cellulose and lignin. This prevents leaching of the chemical from wood during the rainy season and thus offering lasting protection to wood. Used engine oil protected the samples for 7 months without termite attack. This is because oil is water repellent and thus reduces susceptibility of wood to fungal attack. Fungus infected wood is highly susceptible to termite attack compared to sound wood (Matsuo and Nishimoto 1973). Therefore, it is possible that by reducing fungal attack, used engine oil reduced susceptibility of wood to termite attack. It is also likely that the motor oil is directly repellent to termites thus protecting the wood. Nimbecidine used as a source of neem extract (azardirachtin) was meant to control specific organisms i.e. aphids and bollworm of cotton and leaf roller, stem borer and BPH of rice. Since the concentration used was for these specific organisms it might have affected the effectiveness against termites. Protection offered by neem extract is due to the repellent and antifeedant effect by inhibiting the activity of sensory receptors of mouth parts, distorting normal probing, and intake of food. Ingestion of the active ingredients of neem through food also leads to starvation and death (Walter 1999).

\section{CONCLUSION AND RECOMMENDATIONS}

The study showed that untreated sapwood of E. grandis is highly susceptible to termite attack. CCA was most effective in protecting wood against termites, followed by used engine oil and lastly neem extract. Perhaps with increased azadrachtin concentration and better penetration, neem extract could also offer considerable protection to wood. Although engine oil is not recognized as a wood preservative, it can offer protection to wood for some time if it is adequately applied to cover the wood surface. It is recommended that further research be carried out on neem extract using different concentrations.

\section{ACKNOWLEDGEMENTS}

Special thanks to Ms. Florence Ajok, Forest Supervisor (National Forest Authority, Katugo) for her assistance during data collection. We also thank the Uganda Government through Makerere University, for funding the study.

\section{REFERENCES}

Bowyer, J.L.; Shmulsky, R.; Hay- Green, J.G. 2003. Forest products and wood science: an introduction. $4^{\text {th }}$ edition. Iowa state press. USA. 553p.

Darrel, D. 1973. Wood deterioration and its prevention by preservative treatments. Vol.II, preservatives and preservative systems, Syracuse University press, New York, USA.

Johnson, S.W. 2000. Preservative treated wood in the land - scape. University of Nevada, RENO. FACT SHEET 95-29. www.unce.unr.edu/publications/files/ho/other/fs9529.pdf, (consulted $15 / 05 / 2008)$.

Matsuo, H.; Nishimoto, K. 1973. The consumption of fungus infected wood by termite, Coptotermes formosanus Shiraki. http://Repository.kulib.kyoto-u.ac.jp/dspace/.../2433/.../ KJ00000017655.pdf. (consulted 23/05/ 2008).

Nakasongola District Local Government. 2004. District State Of Environment Report For Nakasongola District. NDLG. 2004. http://www.nemaug.org/district_s_o_reports.php (Consulted 04/09/2008) 
Nyeko, P.; Olubayo, M.F. 2005. Participatory assessment of farmers' experiences of termite problems in agro forestry in Tororo district, Uganda. Agricultural research and extension network AgREN. Network paper $\mathrm{n}^{\circ} .143$. www.odi.org.uk/networks/agren/papers/agrenpaper_143.pdf. (consulted 04/09/2008).

Peralta, R.C.G, Menezes, E. B., Carvalho, A.G.; Aguiar-Menezes, E. L. 2004. Wood consumption rates of forest species by subterranean termites (isoptera) under field conditions. $R$. Arvore 28(2):283-289.

Venmalar, D.; Nagaveni, H, C. 2005. Evaluation of copperised cashew nut shell liquid and neem oil as wood preservatives. Institute of Wood Science and Technology. Malleswaram. Bangalore, India. IRG/WP 05-05-0368368. (consulted 05/05/2008). http://www.navimpex.com/vertinnov/ fic_bdd/produits_pdf_fr_fichier/12242579720_Neem+Cashew_wood_preservative.pdf.

Walker, J.C.F. 1993. Primary wood processing: principals and practice. $1^{\text {st }}$ Edition, Chapman and Hall, London. UK. 595p.

Walter, J.F. 1999. Commercial experience with neem products, in methods, in biochemistry, vol.5. biopesticides use and delivery. (consulted 03/06/2008). linkinghub.elsevier.com/retrieve/pii/ S0261219402001758.

Weathersbee III, A.A.; Tang, Y.Q. 2002. Effect of neem seed extract on feeding, survival, and reproduction of Diaprepes abbreviatus (Coleoptera: Curculionidae). Journal of Economic Entomology 95 (4): 661-667. 